
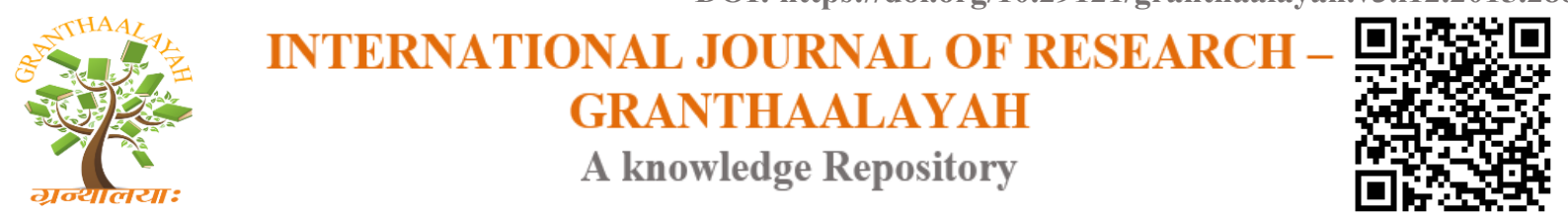

Management

\title{
STUDY OF EFFECTIVENESS OF PERFORMANCE APPRAISAL SYSTEM IN SELECTED INDIAN COMPANIES
}

\author{
Shivali Jindal ${ }^{* 1}$, Laveena ${ }^{2}$, Navneet ${ }^{3}$ \\ ${ }^{*}$ Assistant Professor, Chitkara University, Punjab, INDIA \\ ${ }^{2}$ Assistant Professor and Research Scholar, Chitkara University, Punjab, INDIA \\ ${ }^{3}$ Student, Chitkara University, Punjab, INDIA
}

\begin{abstract}
An evaluation of previous performance is experienced by the vast majority of recruits each year. The management of performance level is the sum up of performance appraisal systems. This is a continuous and interactive process designed to motivate employees, and check their capability with the main motive to facilitate productivity.

The performance management systems involve various activities which are much more than simply reviewing what an employee has done.

This research paper is all about understanding the need of performance management systems, ways in which performance appraisals can be constructed, the occurrence of potential problems, benefits which could be availed and the information of the progress.
\end{abstract}

Keywords:

Performance, Appraisal, performance management.

Cite This Article: Shivali jindal, Laveena, and Navneet, "STUDY OF EFFECTIVENESS OF PERFORMANCE APPRAISAL SYSTEM IN SELECTED INDIAN COMPANIES" International Journal of Research - Granthaalayah, Vol. 3, No. 12(2015): 44-50.

\section{INTRODUCTION}

\section{MEANING OF PERFORMANCE MANAGEMENT}

The perfect setting of performance standards and expectations by observation and providing feedback and the conduct of different appraisal methods helps to achieve the excellent results by managing the performance of the employees. This whole process is known as Performance Management. In other words, it is the process which is designed to understand the pre-fixed work standards in an organization. It is about making a balanced relation between organizational objectives and the skills and competency requirement of employees along with the needed results. The process of PM involves certain activities that make sure that aims and objectives are regularly being obtained in a well effective manner. PM can also be defined as a process which, 
by developing the capabilities and improving the performance of people working for some pre fixed aims and objectives increase the efficiency and effectiveness of a workplace.

\section{HISTORY OF PERFORMANCE MANAGEMENT}

The history of PM goes back 60 years, when it was used to determine the wages of a worker which was based on performance. At that point of time, PM was used as a tool for changing the behavior and working methods of the employees to get certain results but there was a huge gap between justification of wages and development of knowledge and skills it became a large problem for using performance management .In 1980 it was reward managed performance as its need got broader. Due to this understanding the process has become more specialized and dignified.

\section{LITERATURE REVIEW}

Will Artley (2001) discussed that all high performance organizations are interested in developing effective performance measurement and performance mgt. systems since it is only through such system that they can remain high performing. So to attain and maintain the needed level of performance, the performance mgt. systems are needed in the organizations.

Rajeev.V (2008) in his article on Performance management focused on establishing goals for all levels in the center, creating KPIs, delivering role-appropriate scorecards with KPI scores and providing a framework for personal development. A fundamental element of performance management is identifying the right KPIs to focus on for different levels in the center that are also aligned with enterprise goals. The key is to start with an extensive set of predefined KPIs, along with the ability for businesses to create their own general or line-of-business-specific versions. These powerful solutions are impacting businesses across industries and around the globe in measurable ways.

Liliane. M and Peter .M (2010) exclaimed that the performance and competitiveness of different companies can be attainted through implementation of perfectly defined performance measurement indicators and framework that are able to measure the performance function by analysing the use of certain performance indicators in management of maintenance. They discovered that the maximum respondents have very less decisions and changes in processes triggered by performance measurement.

Michael Pitt (2013) highlighted on the fact that Performance management is an essential element to check the performance and quality of properties. This paper determined the recent standards and performance of maintenance management system by studying high-rise private office buildings.

Jorge M. S, Carlos F (2010) expressed that Performance management is the sum up of performance appraisal systems long with wider human resource systems as a means customer to be the focus of strategic organizational, operational and practices. Many manufacturing organizations operate as open systems of operations. In these kind of systems, latest operational technologies of manufacturing are enhanced with modern communication technologies, 
information and to integrate and coordinate operational resources, activities and processes in order to create a stream of value-added operations aimed at capturing and sustaining a competitive benefit and performance management system proves to be very helpful in doing so. Roger.S reviewed six latest performance management studies and organized the key findings into two groups: Performance Management Impact on Organizational Success and Performance Management Trends/ Best Practices that have proven successful for others and affect any organization's bottom line.

Sayantani G, Niladri .D (2013) studied the impact of performance reward systems mainly Performance Related Pay, the role of resources in influencing educational outcomes and the reliability of existing methods of assessing educational performance. They reported the findings which identify the methods of PMS in Indian and international education sector by introducing a new model in performance management system. This model uses three forms to collect information regarding the particular faculty from various sources that are the particular faculty, students and Head of the Department. All this information will be send to the Management for analysis and feedback. Major benefit is transparency.

Neeti and Santosh .C (2015) studied that employees have good knowledge of performance appraisal and have a positive attitude towards it as their promotion is purely based on performance appraisal and the ratings help to fix increments. During the course of study suggestions came from the employees for the need of counselling. Performance appraisal should be made more transparent and rationale.

\section{PERFORMANCE MANAGEMENT IN 21ST CENTURY}

From the past many years, performance management is prevalent and managers have been conducting different levels of performance appraisals and even employees have been receiving training. The methods of performance management in 21 st century are specially designed to make the employees capable of meeting the job expectations and help the managers to identify the inefficiencies and conduct training methods to remove those inefficiencies. The latest and improved technology is also playing an important role in making the performance management in 21 st century more effective and efficient.

\section{PERFORMANCE APPRAISALS}

Performance Appraisal is a method by the usage of which, the level of performance of an employee in doing a job is judged. Moreover, it may also be referred as the performance evaluation, performance review or performance evaluation.

An effective performance management should have the following:

- The ability to review the employment cycle of every individual.

- Balance between the employee skills and abilities and organization's needs and objectives.

- Should provide tools to employees and managers, the tools to focus on the long-term and short-term goals of the organization.

- Reduces the difference between the pre-fixed standards and actual performance.

- Motivates the employees to work. 


\section{THE APPRAISAL PROCESS}

\section{ESTABLISH PERFORMANCE STANDARDS}

MUTUALLY SET MEASUREABLE GOALS

\section{MEASUREMENT OF ACTUAL PERFORMANCE}

\section{COMPARISON OF ACTUAL PERFORMANCE WITH STANDARDS}

\section{DISCUSS APPRAISAL WITH EMPLOYEES}

\section{TAKE CORRECTIVE ACTION}

a) ESTABLISH PERFORMANCE STANDARDS: Firstly, all the standards developing from the strategy of the company should be fixed.

b) MUTUALLY SET MEASUREABLE GOALS: The pre-fixed goals should be in such a manner that they are clear to everyone could be easily understood and measured. After the establishment of standards, they expectations should be made clear to everybody so that the employees need not to guess that what is being expected from them.

c) MEASUREMENT OF ACTUAL PERFORMANCE: After the job has been done, it steps up to the judgment of job done.

d) COMPARE ACTUAL PERFORMANCE WITH STANDARDS: This step involves the noticing of difference between the standard performance expected and the actual work done.

e) DISCUSS THE APPRAISAL WITH THE EMPLOYEES: Discussing the appraisal with the employees is also very important. The feedback which they get for their appraisal is very important to them for their self-confidence plus enthusiasm. That is why it is very significant to talk about the act appraisal with the employees.

f) IF NECESSARY, TAKE CORRECTIVE ACTION: The final step in the evaluation process is to take the corrective action wherever it is required. The corrective action helps to reduce the difference between the actual standards and actual work done. 


\section{METHODS OF PERFORMANCE APPRAISALS}

The following are the methods which are used in the evaluation of performance of the employees:

a) ABSOLUTE STANDARDS: This method includes measuring an employee's performance against established standards. This method also includes other 5 methods of appraisals.

b) RELATIVE STANDARD METHODS: This method includes the evaluation of the performance of an individual by comparing one individual with other individuals.

c) GROUP ORDER RANKING: This method evaluates the performance by ranking the employee's performance from highest to lowest.

d) PAIRED COMPARISON: This includes ranking the job done by noting down the no. of times by which any one individual is provided to be a preferred member while comparing him with other individuals.

\section{PERFORMANCE MANAGEMENT IN TOP MANUFACTURING COMPANIES OF INDIA}

GODREJ: It is the company which was established in 1897 and earns about US \$3.9 billion annual revenue. Over 500 million people use one or another Godrej product everyday .Amongst India's most diversified and trusted brands. Godrej has many initiatives in place to improve Performance Management. They have one team called The Think Tank which include senior managers, these all take corrective steps like in situation of altering tools, customer conduct. They have another team of Young Executive Board which consists of members less than 32 ages. This group mainly gives advice to top level about the performance strategy, mainly on company control, individual source.

Godrej follows various methods to evaluate performance management. Few of them are:

Balanced Score Card: - It is a Strategy performance tool. The managers get the information from various following points:
a) The Customers Perspective
b) The internal business prospective
c) The innovation and learning prospective
d) The financial perspective

Rating System: - The rating system is given against commitments:
a) This is given on all meeting expectations.
b) This is given if not a single work is done.
c) Exceeds expectations.
d) Substantially exceeds expectations. 
Forced Distribution Method: - This is used to rank or appraisal the employees. In this the employees make the managers difficult to choose that who will be chosen by them as the person who is least talented. The reduction in teamwork is its disadvantage.

HINDUSTAN UNILEVER LIMITED: HUL was established in 1933 and its products include beverages, foods, personal care products and cleaning agents. Its distribution system covers over 2 million retail outlets in India and the availability of its products covers 6.4 billion outlets in India. In terms of performance management, according to HUL, the objective of an organization should not be of having the best employees but also to get the best out of them and to retain them.

HINDUSTAN UNILEVER LIMITED uses the following methods in their performance management system:

About 10 to 20 percent of their blue-collared workforces visit their different factories in India and abroad to get an experience and understand the methods of performance being used at different units and to know how workers there operate. HUL has also introduced a new performance appraisal method named as sparkle for its blue-collared workers which will help them to grow in the company. Moreover, the performance management in HUL is done by an online system which includes basically the following process:
a) Annual Goal Setting
b) Mid -Year Review
c) Annual Performance Review

Due to its effective performance management, HUL has become capable of maintaining the attrition level of its blue-collared workers to $2-3 \%$ and of its white-collared workers to about $5 \%$. According to HUL's annual report of 2010-11, the wastage due to loss of man hours was about zero.

\section{CONCLUSION}

Performance Appraisal Management System is going on since a long time and is engulfing the whole industry. Indian companies have also evolved through ages and are following the latest technology and methods for appraisal. After all, whatever employees do throughout the year adorns your salary raise and perks.

\section{REFERENCES}

[1] Beer, $M$ and Ruh, $R A$ (1976) Employee growth through performance management Bernardin HJ, Villanova $P$ (1986). Performance appraisal. In: Locke EA (Ed.), Generalizing from laboratory to field settings: Lexington, MA: Lexington. pp.43-62.

[2] Bernardin HJ, Villanova P (1986). Performance appraisal. In: Locke EA (Ed.), Generalizing from laboratory to field settings: Lexington, MA: Lexington. pp.43-62.

[3] Bernthal, P., Sumlin, R., Davis, P., \& Rogers, R. (1997). Performance Management Practices Survey Report. Development Dimensions International

[4] Jorge M. S,Carlos F (2010) A Literature Review of Maintenance Performance Measurement: Directions for Future Research,Rio D janeiro, sept 2010,1-15 
[5] Locke, E. A. \& Bryan, J. (1968). Goal setting as a determinant of the effects of knowledge of score in performance. American Journal of Psychology, 81, 398-406.

[6] Liliane. M,Peter Muchiri (2010) Empirical Analysis of Maintenance Performance Measurement in Belgian Industries,INTERNATIONAL JOURNAL OF Production RESEARCH, Taylor \& Francis: STM, Behavioural Science and Public Health Titles, 2009, 48 (20), pp.5901-5920

[7] Lingle, J. \& Schiemann, W. (1996, March). Is Measurement Worth It? American Management Association Management Review, 56-61

[8] Michael Pitt, in research in Malaysia in 2013 ,Eksploatacja i Niezawodność, 2013|Vol. 15, no. 2 | 111-116

[9] Neeti, Santosh .C (2015) STUDY OF PERFORMANCE APPRAISAL SYSTEM AND IT'S EFFECTIVENESS IN FMCG INDUSTRY, International Journal of Research \& Development in Technology and Management Science -Kailash, Volume - 22| Issue 1 | 2015,53-63

[10] Research report::Indian FMCG Industry by Action financial services India ltd.(AFSIL)

[11] Rogers, R., Miller, L., \& Worklan, J. (1993). Performance Management: What's HotWhat's Not. Development Dimensions International and the Society for Human Resources Management

[12] Roger.S, Performance Management: Impacts and Trends, Development Dimensions International, Inc. MCMXCVIII. 1-6

[13] Russell, J.S. and Goode, D.L. (1988), "An analysis of managers' reactions to their own performance appraisal feedback”, Journal of Applied Psychology, Vol. 73, pp. 63-7

[14] Sayantani G, Niladri .D (2013) New Model of Performance Management and Measurement in Higher Education Sector, IJSR - INTERNATIONAL JOURNAL OF SCIENTIFIC RESEARCH Volume : 2 | Issue : 8 | August 2013 ,267-274

[15] http://www.tec.govt.nz/Documents/Reports\%20and\%20other\%20documents/Tertiarysector-performance-improving-students-results-aggregate-november-2009.pdf

[16] http://theglobaljournals.com/ijsr/file.php?val=August_2013_1375430474_edd30_86.pdf

[17] http://www.academia.edu/5450806/EFFICACY_OF_PERFORMANCE_MANAGEMENT _SYSTEM_AN_EMPIRICAL_STUDY_AT_ICICI_BANK

[18] http://www.exinfm.com/pdffiles/pm.pdf

[19] http://www.sciencedirect.com/science/article/pii/S1044500500901306

[20] http://en.wikipedia.org/wiki/Performance_management

[21] http://www.managementstudyguide.com/performance-management.htm

[22] http://www.peoplestreme.com/what-is-performance-management.shtml

[23] http://ucsfhr.ucsf.edu/index.php/pubs/hrguidearticle/chapter-7-performancemanagement/

[24] http://www.opm.gov/policy-data-oversight/performance-management/overview-history/

[25] http://www.slideshare.net/ShaikhIrshad/research-proposal-on-performancemanagement-system

[26] http://pure.au.dk/portal/files/55308705/Performance_Management_in_a_21st_Century_ Service_Company.pdf

[27] http://www.contactprofessional.com/solutions/performance-optimization/best-practicesthe-21st-century-approach-performan-961

[28] http://www.orau.gov/pbm/pbmhandbook/Volume\%202.pdf 